\title{
STUDENTS' CRITICAL THINKING PROFILES IN SOLVING MATHEMATICAL PROBLEMS BASED ON ADVERSITY QUOTIENT (AQ)
}

\author{
Nila Nurcahyaning Kusumawardani \\ Mathematics Education, Faculty of Mathematics and Natural Science, Universitas Negeri Surabaya, $e$-mail: \\ nilakusumawardani16030174081@ mhs.unesa.ac.id

\section{Raden Sulaiman} \\ Mathematics Education, Faculty of Mathematics and Natural Science, Universitas Negeri Surabaya, $e$-mail: \\ radensulaiman@unesa.ac.id
}

\begin{abstract}
Critical thinking is a logically thinking process starting from understanding, analyzing, evaluating and making precise conclusions. Critical thinking indicators are clarification, assessment, inference, and strategy that referred to Jacob and Sam. Mathematics is designed to improve students' critical thinking in a solving problem. One of the factors that affect students' critical thinking in solving a problem is AQ. This research is descriptive study with qualitative approach. The aim is to describe critical thinking profile of climber, camper, and quitter students in solving mathematical problems. The subjects were three students of VIII grade junior high school who represented each AQ category and had good communication skills. The instrument used was the ARP questionnaire, mathematics problem solving tests, and interview guidelines. The results shows that students' critical thinking profile in understanding the problem is climber and camper student do all indicators of critical thinking in the clarification phase. Quitter student is only able mentioning known and asked information. In devising a plan, climber student implements all indicators of assessment and strategy phase. Camper student implements all indicators in assessment phase, but do not discuss the possible steps in strategy phase. Quitter student does not do both assessment and strategy phase. In carrying out the plan, climber and camper students do all indicators of inference phase, while quitter student does not. In the step of looking back, only climber student who carries out evaluating steps that have been done.
\end{abstract}

Keywords: Jacob and Sam's critical thinking, mathematical problem solving, adversity quotient.

\section{INTRODUCTION}

Critical thinking is logical and reflective thinking that is focused on making decision (Ennis, 1996). In the same understanding, Krulik and Rudnik (1995) categorize critical thinking as one of the categories of higher-level thinking before creative thinking. Gokhale (1995) defines critical thinking as a thought process that involves the process of analyzing, synthesizing, and evaluating concepts. Siswono (2008) also defines critical thinking as thinking that involves examining, connecting and evaluating all aspects of a problem or situation, including gathering and organizing problems. Meanwhile Hendriana, Rohaeti, \& Sumarmo (2017) clarify the definition of critical thinking that it is a thought process that involves all abilities, such the ability to understand, remember, differentiate, analyze, reason, reflect, interpret, look for relationships, evaluate, evaluate, even to make a temporary conjecture.

Zhou, Huang, \& Tian (2013) state that critical thinking is closely related to education so both of them cannot be separated. Education in Indonesia strongly supports learning systems that can create/develop students' critical thinking. This is supported in the 2013 curriculum development which is presented in four core competencies, precisely in the third core competency that "students must be able to understand, apply, analyze factual, conceptual, procedural knowledge based on their curiosity about science, technology, art, and culture "(Permendikbud, 2016). Similar opinion was also expressed by Chukwuyenum (2013) that the ability to think critically must be included in the development of the curriculum so that students learn and have the ability to be applied in daily life to understand the logical relationship between ideas, make and/or evaluate arguments, as well as solving problems systematically.

There are some experts who express their theories about critical thinking, some of which are Glaciers, Facione, Ennis, Fisher, and Jacob and Sam. Every expert has a little different theory, especially on the indicators used to measure a person's critical thinking. In this research, researcher using the indicators Jacob and Sam's critical thinking (Jacob, 2012), with the acronym category (phases), namely CAIS. CAIS itself represents the categories (phases) in critical thinking, it is clarification, assessment, inference, and strategies. The strongest reason 
of why researcher using Jacob and Sam's critical thinking indicators is because they have perfected the critical thinking indicators of some previous experts. The short explanation of the phases of Jacob and Sam's critical thinking is as follows.

a. Clarification is formulating the problem precisely and clearly.

b. Assessment is finding an important part by raising important questions of a problem.

c. Inference is making conclusions from the informations that has been obtained.

d. Strategy is thinking and proposing thoughts openly in an alternative system of thought.

MMathematics is one of the compulsory lesson given in secondary schools that must be had by students and can be used to improve critical thinking skills. Hendriana, Rohaeti, \& Sumarmo (2017) clarify that the ability to think critically mathematically is an essential mathematical ability that is essential and must be possessed by students in learning mathematics. In additions, according to the Indonesian Minister of Education and Culture's Exposure Press Workshop: Implementation of the 2013 Curriculum states that mathematics is designed so that students must think critically to solve the given problems (Kebudayaan, 2014). So students who are able to think critically will be able to solve the problems effectively.

In a study conducted by Wijaya (2011) concluded that one-third of Indonesian students were only able to work on a problem if all of the information needed was clearly given to the problem, even only $0.1 \%$ of students were able to do the modeling mathematics that demands critical thinking skills. From these results it can be concluded that students' critical thinking skills are still low or unsatisfactory. One reason for the low critical thinking of students is due to habits or traditions in schools that do to teacher-centered learning. The reality that occurs at the moment in most schools is that they tend to provide correct answers rather than generating new ideas, more often using the activities of defining and describing compared to analyzing, evaluating, and creating that is able to bring up students' critical thinking.

Suherman et al (2001: 86) state that a problem usually contains a situation where someone is pushed to solve it even though he/she does not know directly what to do to solve it. Problems in mathematics learning are called mathematical problems. According to Hudojo (2005: 124), a mathematical problem is called a problem for students if: 1) The questions presented must be understood by students and are challenging for students to answer these questions, and 2) these questions cannot be answered by known routine procedures of the student. Polya (1973) divides mathematical problems into two types, namely problem to find which is used to find or obtain certain unknown values, as well as fulfill the conditions that are in accordance with the problem, and problem to prove is used to prove that the statement is true or wrong or not both. Based on some opinions above, the mathematical problem intended in this study is a mathematical problem in the form of a question where the question cannot be answered directly by using routine procedures, but requires certain concepts and strategies. The type of problem to be given is a problem to find. The criteria for mathematical problems in this research are students have obtained prerequisite material as material that has been studied by students, the question is challenging to solve or in other words the problem requires deeper analysis, and having unroutine solving procedure or can be said to require certain concepts and strategies to solve it.

Every problem must have a solution to be solved. The way out of these problems is often called as problem solving. To solve a problem requires the ability to think, one of which is critical thinking. Polya (1981: 1) defines "solving a problem means finding a way out of difficulty". Meanwhile, according to Siswono (2008) "problem solving is a process or individual effort to respond or overcome obstacles when an answer or answer method is not clear yet ". From the two definitions, the meaning of problem solving in this research is an effort to find a solution when it has not found a clear answer from the problem given by using all the knowledge that student has. In the report of the National Examination students of Senior High School in 2019 show that there are some materials where students have low level of problem solving ability. One of them is shown in the indicators of analyzing problem in Systems Linear Equations: Two Variable. In the report obtained that the level of student achievement nationally is $38.41 \%$ far below the average standard set by the government which is $55 \%$. Therefore the material that will be used in this research is Systems Linear Equations: Two Variable (SPLDV).

There are 4 steps of problem solving according to Polya (1973), namely understanding the problem, devising a plan, carrying out a plan, and looking back. While the indicators of critical thinking in problem solving steps used in this research are as follow.

Table 1. Critical Thinking Indicators Based On Each Polya's Problem Solving

\begin{tabular}{|l|c|l|}
\hline \multicolumn{1}{|c|}{$\begin{array}{c}\text { Problem } \\
\text { Solving Steps }\end{array}$} & $\begin{array}{c}\text { Critical } \\
\text { Thinking } \\
\text { Phases }\end{array}$ & \multicolumn{1}{|c|}{ Indicators } \\
\hline $\begin{array}{l}\text { Understanding } \\
\text { the problem }\end{array}$ & Clarification & $\begin{array}{l}\text { Understanding the } \\
\text { scope of the problem. } \\
\text { Analyze the topic of } \\
\text { the problem. }\end{array}$ \\
\hline
\end{tabular}




\begin{tabular}{|c|c|c|}
\hline $\begin{array}{c}\text { Problem } \\
\text { Solving Steps }\end{array}$ & $\begin{array}{c}\text { Critical } \\
\text { Thinking } \\
\text { Phases }\end{array}$ & Indicators \\
\hline & & $\begin{array}{l}\text { Identify the main } \\
\text { information of the } \\
\text { problem. } \\
\text { Mention all the known } \\
\text { informations precisely } \\
\text { and clearly and } \\
\text { mention the asked } \\
\text { information correctly. }\end{array}$ \\
\hline \multirow[t]{4}{*}{$\begin{array}{l}\text { Devising a } \\
\text { plan }\end{array}$} & Assessment & $\begin{array}{l}\text { Group the relevant } \\
\text { information. } \\
\text { Identify the important } \\
\text { or relevant information } \\
\text { that will be used in } \\
\text { problem solving. }\end{array}$ \\
\hline & & $\begin{array}{l}\text { Give relevant } \\
\text { reasons. } \\
\text { Make decisions about } \\
\text { important informasion } \\
\text { based on relevan } \\
\text { reasons. }\end{array}$ \\
\hline & Strateg & $\begin{array}{l}\text { Propose completion } \\
\text { steps that lead to } \\
\text { solution. } \\
\text { Arrange the steps used } \\
\text { in problem solving. }\end{array}$ \\
\hline & & $\begin{array}{l}\text { Discuss the possible } \\
\text { steps. } \\
\text { Determine other } \\
\text { appropriate solving } \\
\text { steps that can be used } \\
\text { in problem solving. }\end{array}$ \\
\hline $\begin{array}{l}\text { Carrying out } \\
\text { the plan }\end{array}$ & inference & $\begin{array}{l}\text { Arrange the relation } \\
\text { of different } \\
\text { information in a } \\
\text { problem. } \\
\text { Carry out the problem } \\
\text { solving by looking at } \\
\text { the relation of each } \\
\text { informatin that has } \\
\text { been collected. }\end{array}$ \\
\hline Looking back & Strategy & $\begin{array}{l}\text { Evaluate the steps } \\
\text { that has been done. } \\
\text { Re-check the problem } \\
\text { solving steps that has } \\
\text { been done. }\end{array}$ \\
\hline
\end{tabular}

Based on researcher observations in a Junior High School, there were $86 \%$ students who had difficulty in solving mathematical problems. This condition gives the laziness impact of students to follow the next mathematics learning. While in fact, the mathematical problems that are given should be looking for the solution.

Everyone has a different ability to survive the problems. It is proven in a mathematics learning that there are some students who have high survive ability and immediately feel challenged to solve the problems given to them. In the other words, these students were hardworking on finding the solutions of the problems. There are also students who if given problems immediately feel give up without trying first. These someone difference ability to survive in dealing thr problems, Stoltz (2000) introduced one of intelligences besides AQ, IQ, and SQ. That intelegence introduced by Stoltz is Adversity Quotion or AQ.

AQ has an important role in an education to estimate how far students are able to defend and deal the problems. Stoltz (2000) divides AQ into three group categories. First category is the climber group. Someone who is in this category means having a high ability to survive in dealing a problem. The next category is the camper group. Someone who is in this group means having middle ability to survive in dealing a problem. The last category is the quitter group. Someone who is in this group means having a low ability to survive in dealing a problem. High and low AQ someone can be known through the results of the Adversity Response Profile Questionnaire.

One of the relevant research is Dian Novita Rohmatin's research who examines the critical thinking profile of junior high school students in solving Geometry problems based on IQ level. The difference research with this research is in the critical thinking phase and also the overview. This research using Jacob and Sam' phase where its critical thinking students is overviewed based on AQ.

Based on the explanation above, the research problem is how the critical thinking profile of climber, camper, and quitter students in solving mathematical problems. Therefore researchers interested in conducting research with the aim of describing the critical thinking profile of climber, camper, and quitter students in solving mathematical problems.

\section{METHODS}

This type of research is a descriptive study with a qualitative approach. The aim of this research is to describe the profile of students' critical thinking in each AQ category, climber, camper, and quitter in solving mathematical problems based on indicators of Jacob and Sam's critical thinking stages.

Students in this research were determined by a purposive sampling technique from the results of ARP (Adversity Response Profile) questionnaire test that 
adapted from Stoltz (2000) and had good communication skills so that three students were obtained where one student had a high AQ score (climber), one student had a medium AQ score (camper), and one student has a low AQ score (quitter). This research had been done in VIII grade exactly in the even semester of 2019/2020.

The instruments used in this research were ARP questionnaire, mathematics problem solving test (TPMM), and interview guidelines. The ARP questionnaire test is used to determine students into the AQ category. Mathematical problem solving tests (TPMM) are used to know how the students' critical thinking phases in solving mathematical problems. TPMM in this research is a question of mathematical problem solving related to the linear equation system with two-variable. While the interview is used to know detail information about the phases of critical thinking that is not obtained from the results of mathematics problem solving test.

The data collection technique using two methods, namely test and interview methods. The data analysis technique using three methods, namely the result of ARP questionnaire analysis then analysis the result of TPMM and interviews. The steps of qualitative data analysis include data reduction, data presentation, and making conclusion.

\section{RESULTS AND DISCUSSION}

After collecting data about the ARP questionnaire test and categorized based on ARP scores is obtained that $2.5 \%$ of students included in the climber category, $17.5 \%$ of students included the transition from camper to climber category, $27.5 \%$ of students included the camper category, $22.5 \%$ students including the transition from quitters to camper category, and $30 \%$ of students are in the quitter category. From these data, three students were selected through purposive sampling technique who had good communication skills and represented each AQ category, namely one student with a high ARP score (CL), one student with a middle ARP score (CM), and one student with a low ARP score (QT). Based on the results of data analysis that has been done it is known that each student has a different way to do the mathematical problem solving tests given. These differences can be seen based on how students understanding the problems, choosing what information is used and not used in a solution, making conclusions based on information obtained, and planing the problem solving.

\section{Climber Students' Critical Thinking Profiles in Solving Mathematical Problems.}

In the step of understanding the problem, the CL ways to do the clarification phase is to analyze the scope of the problem of the two given problems by reading the questions first then continuing to retell the questions given using their own language. CL knows the topics of both problems are related to linear equation system with two-variable (SPLDV).

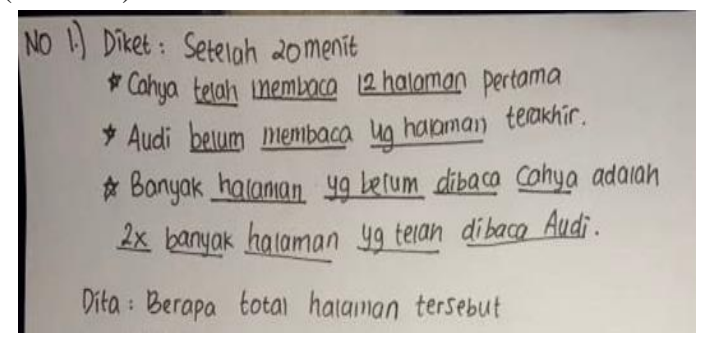

Figure 1. Understanding the problem step (clarification phase) in problem number 1

For the problem number 1, CL mentions all the information in the problem precisely and clearly through the interview. CL writes down what information is asked correctly, but not written in detail the information as we can see in the figure 1 . While the problem number 2, CL writes precisely and clearly all informations both of what known and asked information in the problem as in the figure 2 .

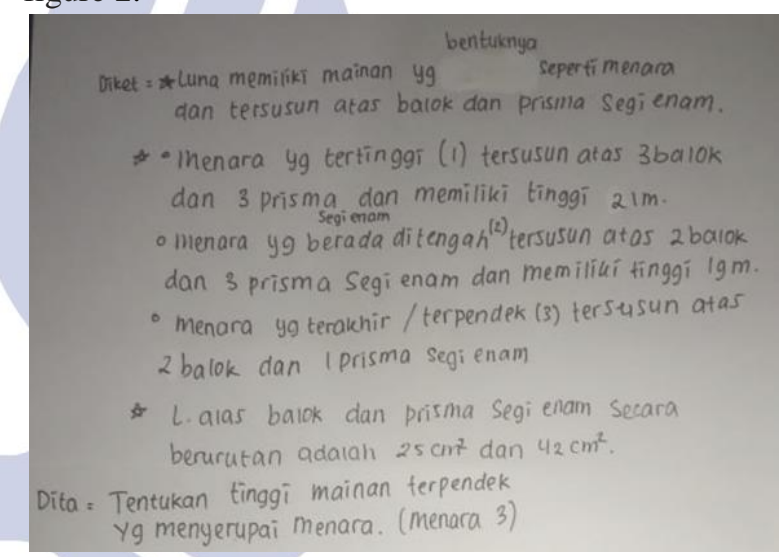

Figure 2. Understanding the problem step (clarification phase) in problem number 2

After callecting all informations in the problem, the next step is devising a plan. In this step, CL identifies the informasions by grouping what information is includ in the important or relevant information for both problems. CL can also make the right decision based on the reasons that only relevant information will be used in the solution. After determining the relevant information, CL is able to decide on the solution steps that lead to the problem solving. The solution steps are shown in the following interview part.

Table 2. CL's Interview Part In Devising A Plan For Problem 1

\begin{tabular}{|l|l|}
\hline PpCL1_10 & $\begin{array}{l}\text { Oke. Now, how do you solve for } \\
\text { the problem number 1? }\end{array}$ \\
\hline JsCL1_10 & $\begin{array}{l}\text { First I make a supposing then } \\
\text { making the equations. After that } \\
\text { I use substitution method to } \\
\text { solve it. }\end{array}$ \\
\hline
\end{tabular}




\begin{tabular}{|c|c|}
\hline PpCL1_11 & $\begin{array}{l}\text { You have said that you make a } \\
\text { supposing. What supposing that } \\
\text { you made? Because I do not } \\
\text { know about your supposing in } \\
\text { your answer sheet. }\end{array}$ \\
\hline JsCL1_11 & $\begin{array}{l}\text { I have write it in the question } \\
\text { sheet, miss. Suppose } y \text { as the } \\
\text { pages that has not been read yet } \\
\text { by Cahya. While } x \text { as the pages } \\
\text { that has been read by Audi. }\end{array}$ \\
\hline PpCL1_12 & $\begin{array}{l}\text { How you can write Cahya }=12 \\
+\mathrm{y} \text { and Audi }=\mathrm{x}+49 ?\end{array}$ \\
\hline JsCL1_12 & $\begin{array}{l}\text { Because Cahya and Audi read } \\
\text { the same book, so I use an equal } \\
\text { sign, miss. While I have } \\
\text { supposing variable for } x \text { and } y \\
\text { then I use my logical think from } \\
\text { these kown informations thatt } \\
\text { Cahya has been read } 12 \text { pages } \\
\text { and Audi has not been read } 49 \\
\text { pages. So I have Cahya }=12+ \\
y \text { and Audi }=x+49 \text {. }\end{array}$ \\
\hline PpCL1_13 & $\begin{array}{l}\text { You use substitution method } \\
\text { right? }\end{array}$ \\
\hline JsCL1_13 & $+>$ \\
\hline PpCL1_14 & $\begin{array}{l}\text { Can you tell me, how is the way } \\
\text { og that method? }\end{array}$ \\
\hline JsCL1_14 & $\begin{array}{l}\text { In the known information given, } \\
\text { I change the information of the } \\
\text { pages that has not been read yet } \\
\text { by Cahya is two times the pages } \\
\text { that has been read by Audi } \\
\text { becomes } y=2 x \text {. Then I } \\
\text { subtitute that equation into } 12+ \\
y=x+49 \text {. So I get the value } \\
\text { of } x \text {. After that I subtitute the } \\
\text { value of } x \text { in } y=2 x \text {. So I get } \\
\text { the value of } x \text { and } y \text {. Finally I } \\
\text { subtitute both value } x \text { and } y \text { into } \\
\text { Cahya's equation, it is } 12+y \text {. } \\
\text { So I get the total pages of the } \\
\text { book. }\end{array}$ \\
\hline
\end{tabular}

The interview part above exactly in the JsCL1_10 code shows how the CL ways in solving the problem for number 1 . CL decides to use the substitution method and can explain every solution step by step. Meanwhile, to solve the problem of number 2, CL uses a mixed method of both substitution and elimination and can explain how to solve it as shown in interview part exactly in JsCL2_11 code below.

Table 3. CL's Interview Part In Devising A Plan For Problem 2

\begin{tabular}{|l|l|}
\hline PpCL2_10 & $\begin{array}{l}\text { Next please explain to me } \\
\text { what method that you use to } \\
\text { solve this problem? }\end{array}$ \\
\hline JsCL2_10 & Using mix method, miss. \\
\hline PpCL2_11 & How is that? \\
\hline
\end{tabular}

\begin{tabular}{|l|l|}
\hline JSCL2_11 & $\begin{array}{l}\text { First I make a supposing } \\
\text { variable, } x \text { as cuboid and } y \text { as } \\
\text { hexagonal prism. Then I make } \\
\text { the equations of the higest/first } \\
\text { tower, middle/second tower, } \\
\text { and the lowest/third tower. } \\
\text { Because the first and second } \\
\text { tower have } 3 y \text { in their } \\
\text { equation, then I subtract both } \\
\text { equation and I get the value of } \\
x \text { which I will substitute it into } \\
\text { second tower equation to get } \\
\text { the value of } y \text {. The last, } \\
\text { because the problem ask me to } \\
\text { find the height of the tirs } \\
\text { tower, so I substitute the value } \\
\text { of } x \text { and } y \text { into third tower } \\
\text { equation. }\end{array}$ \\
\hline
\end{tabular}

After deciding the solution step, CL can show an alternative answer that can be used to solve both of the problems given. For the problem number 1, CL can solve the problem by using a substitution method that is different from the first substitution method that has been done. The difference of both methods is in the supposing variable where for the alternative answer CL uses a linear equation with one variable. Both results of solution have the same answer. For the problem number 2, CL finds the same final result using the mixed method.

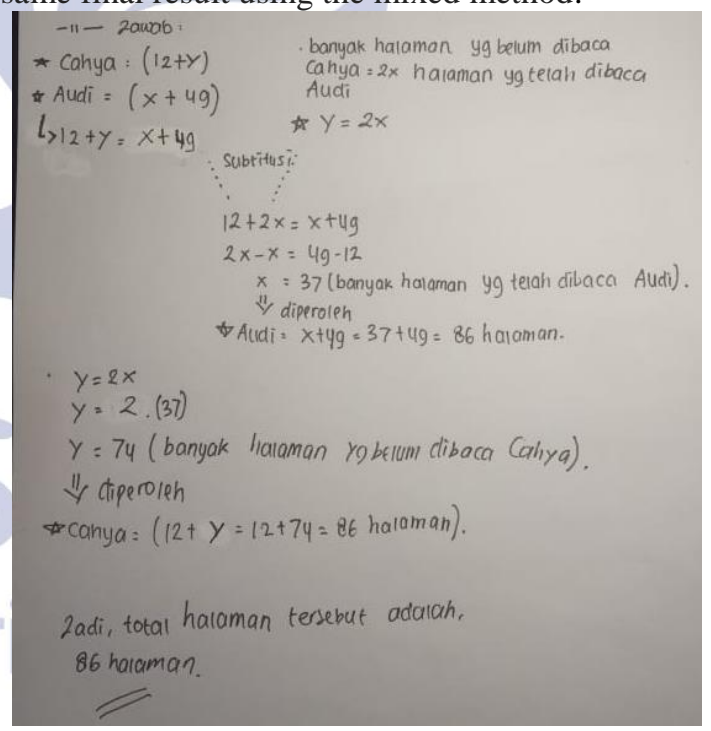

Figure 3. Carrying out the plan step (inference phase) in problem number 1 


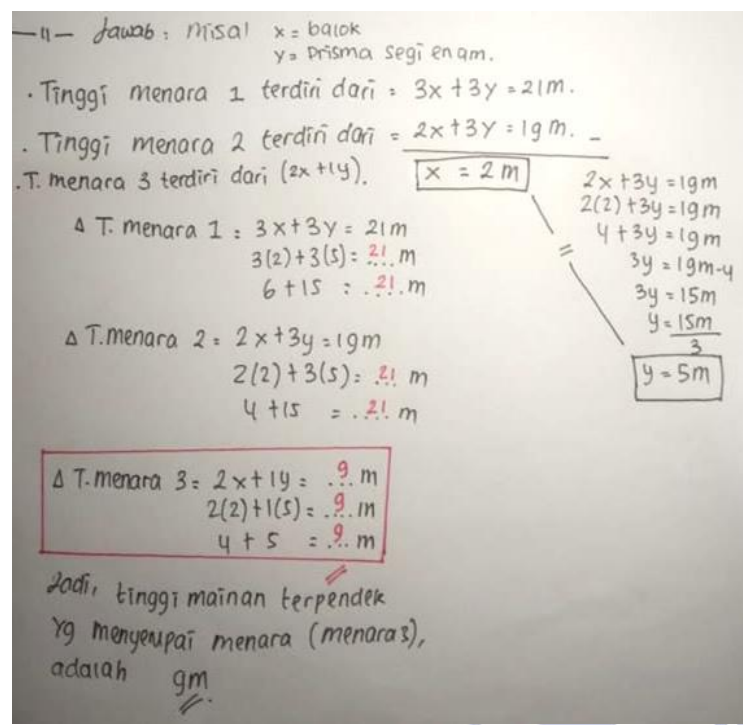

Figure 4. Carrying out the plan step (inference phase) in problem number 2

The next step is carrying out the plan. In solving of both problem given, CL is able to carry out the problem solving by using collecting informations based on what has been planned which is showed in figure 3 and 4. CL can make the right conclution based on the problem solving steps that has be done.

The last step of solving a prolem is looking back. In this step CL did the evaluation or looking back every single step of the solving problem. Besides that, the last way $\mathrm{CL}$ in re-checking to do the problem solving is by substituting the results of the value of $x$ and $y$ that have been found. For the problem number 1 , the value of $x$ and $y$ will be substitute in the total page of the book equation that has been read by Cahya is $12+y$ and the total page that has been read by Audi is $x+4$. Likewise the problem number 2 , CL do re-checking the problem solving steps by substituting the value of $x$ and $y$ variable into the first and second tower equation.

Through the researcher observations, CL has same characteristics with what Stoltz (2000) says of someone characteristics in solving a problem. The CL characteristics when did solving given problem are not easily felt dispirited when did the problem. Even CL felt challenged by the problem given because CL has a high curiosity how to solve it. Based on the discussion described above, CL can did well all critical thinking indicators in Polya's problem solving steps such Hidayat's research results (2018) that climbers students have good problem solving steps because they can solve the problems based on indicators that are has been established.

2. Camper Students' Critical Thinking Profiles in Solving Mathematical Problems.

In the step of understanding the problem in clarification phase, CM can analyze the scope of the problem for the two problems given. The first step taken by $\mathrm{CM}$ in understanding this problem by reading two to four times to understand the questions. After understanding the given problem, $\mathrm{CM}$ can retell both problems correctly given using CM's own language. CM had thought for a moment about what material is related to the problem. Finally CM decided that the topic of the problem was related to the SPLDV.

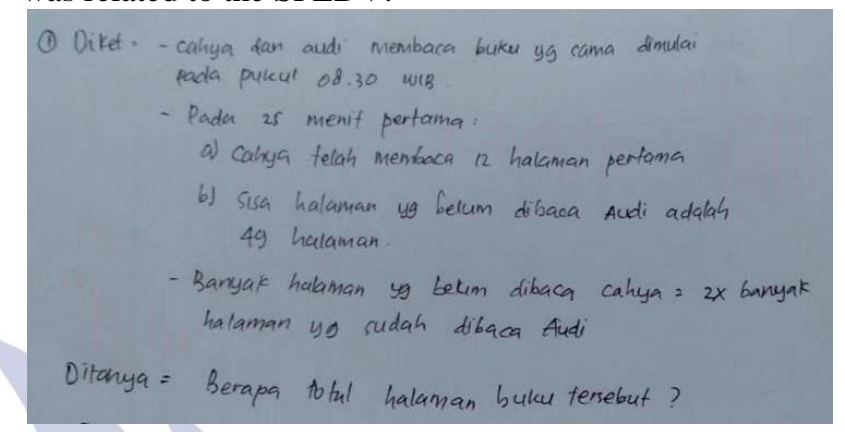

Figure 5. Understanding the problem step (clarification phase) in problem number 1

In the $\mathrm{CM}$ answer sheet for question number 1, CM writes all information in detail and completely which is showed in figure 5. Besides that, $\mathrm{CM}$ can also mentions asked information precisely and clearly.

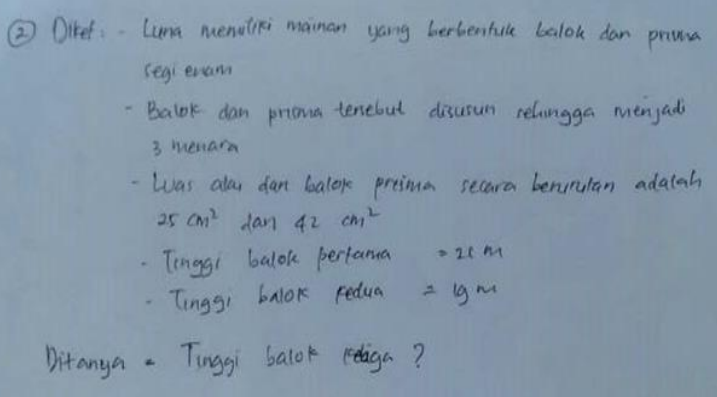

Figure 6. Understanding the problem step

(clarification phase) in problem number 2

Similar to number 1 , for problem number 2 $\mathrm{CM}$ writes all the information fully as showed in figure 6. However, there are two informations written by $\mathrm{CM}$ exactly in known information which makes the researcher confuse because of unclearly information. Both informations are the height of the first cuboid $=21 \mathrm{~m}$ and the height of the second cuboid $=19 \mathrm{~m}$. These two informations are confusing because in the problem given is not shown about the height of the cuboid, but it shows the height structure of thetower that consists of cuboid and hexagon prism which have 21 meters and 19 meters in height. Through the interview, $\mathrm{CM}$ can explain its unclear information. Bellow is an interview part with code JsCM2_8 that clarifies the information.

Table 4. CM Explanations Of The Unclear Indormation

\begin{tabular}{|l|l|}
\hline PpCM2_7 & $\begin{array}{l}\text { Oke now you have understand } \\
\text { right? Then try to retell the } \\
\text { problem with your own } \\
\text { language! }\end{array}$ \\
\hline
\end{tabular}




\begin{tabular}{|c|c|}
\hline JsCM2_7 & $\begin{array}{l}\text { Oke miss. For the problem } \\
\text { number } 2 \text {, there is someone her } \\
\text { name is Luna. She has toy looks } \\
\text { like a tower that shows in the } \\
\text { problem picture. Its tower are } \\
\text { construsted with cuboid and } \\
\text { hexagonal prism. Then she } \\
\text { arranges cuboid and hexagonal } \\
\text { prism become a tower. The first } \\
\text { tower consists of three cuboids } \\
\text { and three hexagonal prisms that } \\
\text { has } 21 \text { meters in height. The } \\
\text { second tower consists of two } \\
\text { cuboids and three hexagonal } \\
\text { prisms that has } 19 \text { meters in } \\
\text { height. While the third tower } \\
\text { consists of two cuboids and a } \\
\text { hexagonal prism. Both of base } \\
\text { area of cuboid and hexagonal } \\
\text { prism respectively are } 25 \mathrm{~cm}^{2} \\
\text { and } 42 \mathrm{~cm}^{2} \text {. Then for the asked } \\
\text { information is how is the height } \\
\text { of tshortes tower? The shortest } \\
\text { tower means the third tower } \\
\text { miss. }\end{array}$ \\
\hline PpCM2_8 & $\begin{array}{l}\text { But why you write in the known } \\
\text { information is for the first } \\
\text { cuboid is equal to } 21 \mathrm{~m} \text { in height } \\
\text { and the second cuboid is equal } \\
\text { to } 19 \mathrm{~m} \text { ? What do you mean? }\end{array}$ \\
\hline JsCM2_8 & $\begin{array}{l}\text { I mean that it is the height of the } \\
\text { tower, miss. The tower consists } \\
\text { of cuboid and hexagonal prism } \\
\text { right? So I wrong write there, I } \\
\text { just write for the cuboid. }\end{array}$ \\
\hline
\end{tabular}

Next is the step of devising a plan. In planning problem solving number 1 , the first step taken by $\mathrm{CM}$ to solve problem number 1 is determine which is important or relevant information that can be used to solve the problem. The CM also provides precise reasons why the information was chosen as relevant information. CM used substitution method to solve the problem which is described in the code JsCM1_12 of the interview part.

Table 5. CM's Interview Part In Devising A Plan For Problem 1

\begin{tabular}{|l|l|}
\hline PpCM1_12 & $\begin{array}{l}\text { Try to explain how is the way to } \\
\text { used in this problem solving? }\end{array}$ \\
\hline JsCM1_12 & $\begin{array}{l}\text { Oo, I use this picture, miss } \\
\text { (showing the illustartion that } \\
\text { she has drawn in her answer } \\
\text { sheet). First I make the } \\
\text { supposition the total page of the } \\
\text { book using a rectangular } \\
\text { illustration. Then I find the } \\
\text { equation of the pages that has } \\
\text { not been read yet by Cahya is } \\
\text { and the pages that has been } \\
\text { read by Audi. Suppose } x \text { as the } \\
\text { pages that has not been read yet }\end{array}$ \\
\hline
\end{tabular}

\begin{tabular}{|l|l|}
\hline \multirow{7}{*}{} & $\begin{array}{l}\text { by Cahya and } y \text { as the pages } \\
\text { that has been read by Audi. } \\
\text { Then I substitute to this known } \\
\text { information, miss (showing to } \\
\text { the information of the pages } \\
\text { that has been read yet by Cahya } \\
=2 \mathrm{x} \text { the pages that has been } \\
\text { read by Audi). After that I get } \\
\text { the result of the total pages of } \\
\text { its book. }\end{array}$ \\
\hline PpCM1_13 & $\begin{array}{l}\text { So, what type of method that } \\
\text { you use in this problem solving? }\end{array}$ \\
\hline JsCM1_13 & \begin{tabular}{l} 
I use substitution method miss. \\
\hline
\end{tabular}
\end{tabular}

Just like the first step planning in problem number 1, CM also does the same plan to solve the problem in number 2, $\mathrm{CM}$ can determine which is the important information and is used in problem solving with the right reasons. The problem solving method used to solve in problem number 2 is also different from number 1. CM uses a mixed method to solve problem number 2 . Interview part bellow with code JsCM2_13are shown as CM explanations regarding solution steps that lead to the problem.

Table 6. CM's Interview Part In Devising A Plan For Problem 2

\begin{tabular}{|l|l|}
\hline PpCM2_13 & $\begin{array}{l}\text { Oke, next how is your way to } \\
\text { solve this problem? }\end{array}$ \\
\hline JsCM2_13 & $\begin{array}{l}\text { First I make the mathematical } \\
\text { modelling, the first tower } \\
\text { becomes } 3 x+3 y=21 m, \\
\text { while the second tower is } 2 x+ \\
3 y=19 m . \text { Then I subtract both } \\
\text { equations and I get the value of } \\
x \text { and } y \text {. Finally I substitute the } \\
\text { value of } x \text { and } y \text { to the height of } \\
\text { the tower that asked in the } \\
\text { problem. }\end{array}$ \\
\hline PpCM2_14 & $\begin{array}{l}\text { So where is your supposition in } \\
\text { your answer sheet? }\end{array}$ \\
\hline JsCM2_14 & $\begin{array}{l}\text { Oh, I write it in the problem } \\
\text { paper miss. I have underline for } \\
\text { the suppotion, } x \text { as the cuboid } \\
\text { and } y \text { as hexagonal prism. }\end{array}$ \\
\hline
\end{tabular}

$\mathrm{CM}$ said that $\mathrm{CM}$ had no idea to discuss alternative solutions for both problems given, felt difficult and required a relatively long time to solve the problem.

The next step of problem solving is carrying out the plan. In the steps in solving of both problems given, $\mathrm{CL}$ is able to carry out the problem solving by using collecting informations based on what has been planned, but CM did not write the conclusions from the obtained results which is showed in figure 7 and 8 . 


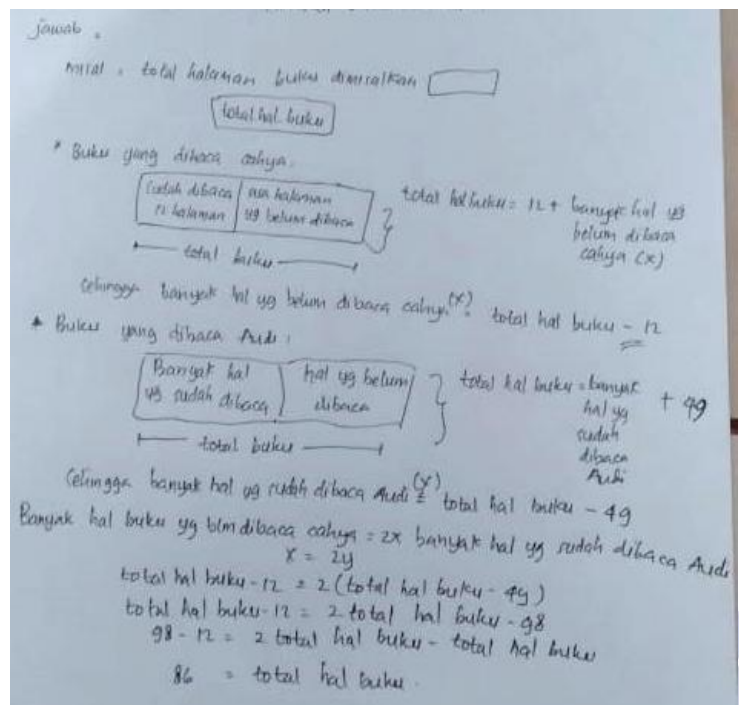

Figure 7. Understanding the problem step (clarification phase) in problem number 1

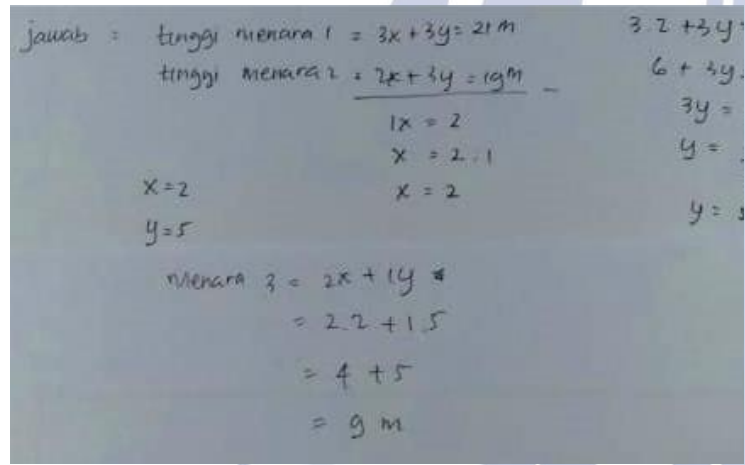

Figure 8. Understanding the problem step (clarification phase) in problem number 2

However, CM can make conclusions that are appropriate to the results of the solution obtained through interviews. While the last step in a solving mathematical problems is looking back. In this last step, the CM does not carry out the evaluation phase, which means CM does not re-check the step by step that has been done.

Based on the problem-solving steps taken by the $\mathrm{CM}$ above, it can be conslude that $\mathrm{CM}$ has not a dispririt character easily. This can be seen in the activities carried out by $\mathrm{CM}$ in understanding the problem. To understand the problem given, $\mathrm{CM}$ tries to understand the problem by reading it in many times. But CM was satisfied when CM found the result. We know from CM activities show when $\mathrm{CM}$ does not have the idea to think the alternative solution because the problem is difficult and requires a relatively long time to solve. These characteristics are corresponds that expressed by Stoltz (2000).

3. Quitter Students' Critical Thinking Profiles in Solving Mathematical Problems.

In analyzing the scope of the problem in the step of understanding the problem, the QT ways to understand the problem given is by reading the both problem in many times. Actually QT understands both problems, but QT does not know how to solve it. When the researcher did the interviewed, QT only guessed that the way to do both problems was using addition and multiplication operations only. QT also did not write all the informations given problems in full and clearly which is showed in figure 9.

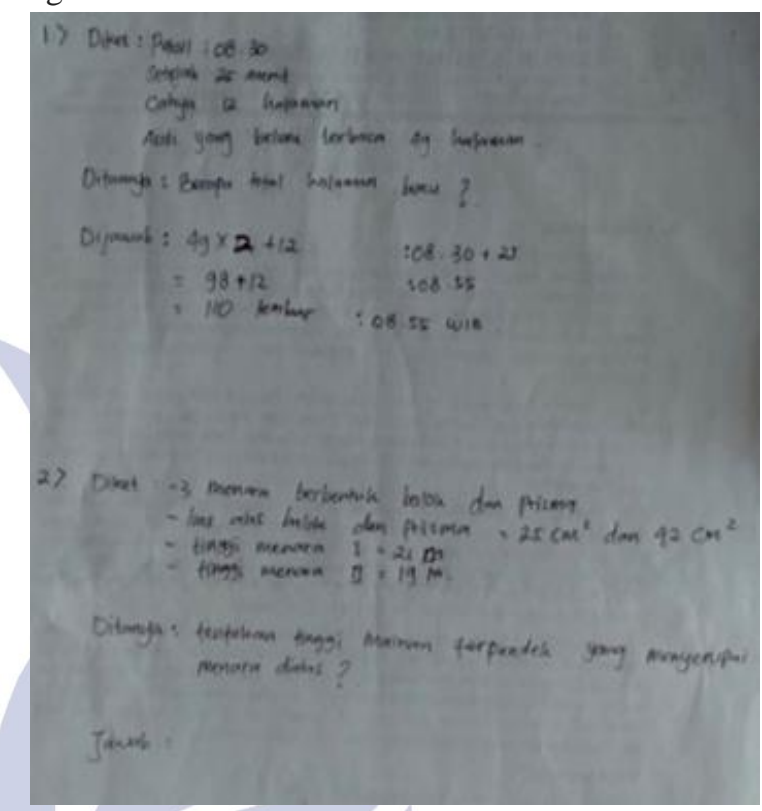

Figure 9. TPMM answer for the problem number 1 and 2

Although QT QT did not write the known informations given problems clearly, but QT can write down what is asked information for each problem precisely.

In solving mathematical problems, QT is only able to take understanding the problem steps. In fact, not all indicators done, QT is only able to write asked information precisely. While for the known information, QT cannot write and mention all the informations precisely and clearly.

Based on the discussion above, it can be concluded that QT has a low ability to solve a problem. QT fells give up first before finding the right way out. These characteristics are corresponds that expressed by Stoltz (2000).

Based on the explanation above, the differences critical thinking indicators of each students in Polya's problem solving are summerized bellow.

Table 7. The Critical Thinking Indicators that Done By Each AQ Student Category

\begin{tabular}{|l|c|c|c|}
\hline \multicolumn{1}{|c|}{ Indicator } & Climber & Camper & Quitter \\
\hline $\begin{array}{l}\text { Understanding the } \\
\text { scope of the problem }\end{array}$ & $\sqrt{ }$ & $\sqrt{ }$ & - \\
\hline $\begin{array}{l}\text { Identify the main } \\
\text { information of the } \\
\text { problem }\end{array}$ & $\sqrt{ }$ & $\sqrt{ }$ & $\sqrt{ }$ \\
\hline
\end{tabular}




\begin{tabular}{|l|c|c|c|}
\hline \multicolumn{1}{|c|}{ Indicator } & Climber & Camper & Quitter \\
\hline $\begin{array}{l}\text { Group the relevant } \\
\text { information }\end{array}$ & $\sqrt{ }$ & $\sqrt{ }$ & - \\
\hline $\begin{array}{l}\text { Give relevant } \\
\text { reasons }\end{array}$ & $\sqrt{ }$ & $\sqrt{ }$ & - \\
\hline $\begin{array}{l}\text { Propose completion } \\
\text { steps that lead to } \\
\text { solution }\end{array}$ & $\sqrt{ }$ & - & - \\
\hline $\begin{array}{l}\text { Discuss the possible } \\
\text { steps }\end{array}$ & $\sqrt{ }$ & $\sqrt{ }$ & - \\
\hline $\begin{array}{l}\text { Arrange the relation } \\
\text { of different } \\
\text { information in a } \\
\text { problem }\end{array}$ & $\sqrt{ }$ & - & - \\
\hline $\begin{array}{l}\text { Evaluate the steps } \\
\text { that has been done }\end{array}$ & &
\end{tabular}

\section{CLOSURE}

\section{Conclutions}

Based on the results of data analysis and discussion above, the following conclusions are obtained bellow.

\section{Climber Students' Critical Thinking Profiles in Solving Mathematical Problems.}

In a solving mathematical problems, climber students carri out all indicators of critical thinking. The first step is understanding the problem. In the clarification phase, climber students know the scope or topic of the problem and can determine the known and asked information.

The second step in solving mathematical problems is devising a plan. In the assessment phase did by climber student is grouping the information that is important or relevant information and provide right decisions based on relevant reasons. While in the strategy phase, the climber student can show the possible steps or alternative solutions that are due to problem solving.

The next step in solving mathematical problems is to carrying out the plan. Climber student can carried out plans that have been planned using information that has been collected before and in the inference phase climber students can make right conclusions based on the obtained results.

The last step in solving mathematical problems is looking back. In this step, the strategy used by climber student is to evaluate or re-check every single steps of the solving problem.

2. Camper Students' Critical Thinking Profiles

\section{in Solving Mathematical Problems.}

In solving mathematical problems, camper students do not do some critical thinking indicators namely the strategy phase in the part of discussing possible steps and evaluating the steps that have been taken.
The critical thinking phase that carried out by camper students in the step of understanding the problem is the clarification phase by knowing the scope or topic of the problem given and can determine the known and asked information.

The second step in solving mathematical problems is devising a plan. In this step, the assessment phase did by camper students is grouping the information that is important or relevant information and provide right decisions based on relevant reasons. While the next critical thinking phase is camper student can determine the solution strategy that lead to the problem solving. However, the camper student cannot show the possible steps or alternative solutions that are due to problem solving.

The next step in solving mathematical problems is carrying out the plan. Camper student can carry out plans that have been planned well and can make conclusions from the obtained results.

The last step in solving mathematical problems is looking back. In this last phase camper student did not an evaluation or re-check every single steps of the solving problem.

3. Quitter Students' Critical Thinking Profiles in Solving Mathematical Problems.

Different with climber and camper students. Quitter students are only able to do the clarification phase in the step of understanding the problem. Not all critical thinking indicators in the clarification phase are carried out by quitter students. Only one indicator of critical thinking is done, namely mentioning the asked information correctly. While for the known information, the quitter students can not mention all the known informations completely given in the problems.

\section{Suggestions}

After knowing the differences about how climber, camper, and quitter students in solving mathematical problems based on the conclusions above, given there are some suggestions bellow:

1. For teachers, start giving questions that can develop students' critical thinking skills, and accustom students with understanding the problem carefully, teach students to do the problems in detail, step by step, and carefully. In addition, it is better if the teacher pays attention to the student's AQ in teaching and learning process to minimize learning difficulties and can improve students' critical thinking skills. One of the ways that can be done to appropriate the learning method by forming a group study that consists of three AQ categories. 
2. For other researchers, can conduct similar research to find out the other students' critical thinking profile with different views. So it can make variety resulting of critical thinking research.

\section{REFENCES}

Chukwuyenum, A. N. (2013). Impact of Critical thunking on Performance in Mathematics among Senior Secondary School Students in Lagos State. IOSR Journal of Research \& Method in Education.

Ennis, Robert H. (1996). Critical Thinking. Upper Saddle River: Prentice Hall.

Gokhale, A. A. (1995). Collaborative Learning Enhances Critical Thinking. [Online]. Tersedia: http::/Scholer.lib.vt.edu./ejournals/JTEI V7 n1/pdf/Gokhale.pdf

Hendriana, H, dkk. (2017). HARD SKILLS dan SOFT SKILLS MATEMATIK SISWA. Bandung: PT Refika Aditama.

Hidayat, W., \& Sariningsih, R. (2018). Kemampuan Pemecahan Masalah Matematis dan Adversity Quotient Siswa SMP Melalui Pembelajaran Open Ended. JNPM (Jurnal Nasional Pendidikan Matematika), 2(1), 109-118.

Hudojo, Herman. (2005). Pengembangan Kurikulum dan Pembelajaran Matematika. Malang: UM Press.

Jacob, S. M. (2012). Mathematical achievement and critical thinking skills in asynchronous discussion forums. Procedia - Social and Behavioral Sciences, 31(2011), 800-804.
Kebudayaan, K. P. (2014). Paparan Menteri Pendidikan dan Kebudayaan RI Press Woekshop: IMPLEMENTASI KURIKULUM 2013. Jakata.

Krulik, Stephen \& Rudnick, Jesse A. (1995). The New Sourcebook for Teaching Reasoning and Problem Solving in Elementary School. Needham Heights, Massachusetts: Allyn \& Bacon.

Pendidikan, K. (2016). Implementasi Kurikulum 2013 Sd Mi. Jurnal Inovasi Pendidikan, 1(3).

Permendikbud. 2016. Standar Isi Pendidikan Dasar dan Menengah No. 21. Jakarta: Kemendikbud.

Polya, G. 1973. How to Solve It. New Jersey: Princenton University Press.

Rohmatin, D. N. (2012). Profil Berpikir Kritis Siswa SMP Dalam Memecahkan Masalah Geometri Ditinjau darii Tingkat IQ. Gamatika, 3(1).

Siswono, T. Y. E. (2008). Berpikir Kreatif melalui Pemecahan dan Pengajuan Masalah. Surabaya: UNESA.

Stoltz, P. G. (2000). Adversity Quotient: Mengubah Hambatan Menjadi Peluang. (Alih Bahasa: $T$. Hermaya). Jakarta: Grasindo.

Suherman, dkk. (2001). Strategi pembelajaran matematika kontemporer. Bandung: JICA.

Wijaya, Ariyadi. (2011). Pendidikan Matematika Realistik. Yogyakarta: Graha Ilmu.

Zhou, Q, dkk. (2013). Developing Students' Critical Thinking Skills by Task-Based Learning in Chemistry Experiment Teaching. Scientific Research, 40. 